\title{
The arthritis sufferer and the community: a comparison of arthritis sufferers in rural and urban areas
}

\author{
PAUL G J CORNELISSEN, ${ }^{1}$ JOHANNES J RASKER ${ }^{2}$ \\ AND HANS A VALKENBURG
}

From the ${ }^{1}$ Department of Epidemiology, Erasmus University, Rotterdam, The Netherlands; ${ }^{2}$ Ziekenhuis Ziekenzorg, Enschede, The Netherlands; and the ${ }^{3}$ Department of Epidemiology, Erasmus University Rotterdam, The Netherlands

SUMMARY One hundred and two rural patients and 100 urban patients with rheumatoid arthritis and osteoarthrosis and 203 age and sex matched controls were visited in their homes to evaluate their problems, needs, and expectations. Although one would expect disability to affect theg mobility of a person, it was found that rural patients were more mobile than their urban counterparts despite the same degree of functional disability. They were more content with their lot, even though their circumstances were less favourable. Both groups of patients had little contact with their general practitioners, social workers, or district nurses, and lacked information about their disease and the availability of financial grants or home adaptations. The man problem for the individual patient was not pain, but the frustration of being unable to do things they used to do and of dependency on others.

There are many rheumatic diseases which give rise to longlasting illness and may result in disability. Not only are the patients affected by the illness, but also their family and friends.

In earlier times the relatives and community helped the patients and their families ${ }^{1}$; this is still often the case in rural environments, but is becoming less common in industrialised urban society. ${ }^{2}$ This means that medical and social services are expected to give help; often in this situation the professional takes decisions about the patient's welfare without prior consultation.

Relatively few studies have been performed to evaluate the consequences of chronic rheumatic diseases on the daily life of patients with arthritis ${ }^{3-6}$; little may be known about the patient's wishes and many professionals are unaware of how the patient perceives his situation. As the setting in which handicap develops differs in rural and urban areas it is likely that the perceptions and experiences of affected individuals will also differ according to environment. We therefore undertook a study to determine the main problems encountered by the patients and to assess their ideas, wishes, and expectations.

Accepted for publication 24 July 1987.

Correspondence to Dr Johannes J Rasker, Ziekenhuis Ziekenzorg. Haaksbergerstraat 55, 7513 ER Enschede, The Netherlands.

\section{Patients and methods}

In the city of Enschede (150 000 inhabitants) añ the surrounding countryside 405 people were visite at home. The sample consisted of 100 urban and $1 \overline{(2)}$ rural patients with arthritis and two groups of 103 and 100 age and sex matched controls. 'Urba施 indicates a city with more than 100000 inhabitants 'Rural' implies either a village where more tha $20 \%$ of the population work in agriculture or ay urbanised rural community where although less tha $20 \%$ of the population work on the land, the population is less than 20000 and the community has no explicit regional service function. Thus rurol subjects may live in or near the centre of a village of in a farmhouse more or less isolated in the countr. side.

All patients with arthritis had walking problenos and classical or definite rheumatoid arthritis (RA) according to American Rheumatism Associatiou criteria, ${ }^{8}$ or osteoarthrosis (OA) with knees or hips or both, affected. Classification according to Steif brocker et al ${ }^{9}$ was carried out by J J R, who did nôt visit the patients at home. Amalia Harris ${ }^{10}$ classi cation was performed by $\mathrm{P} \mathrm{G} \mathrm{J} \mathrm{C} \mathrm{in} \mathrm{the} \mathrm{patients}$ home.

The urban group consisted of 100 consecuti㠃 patients, who were asked during outpatient clingc 
visits to join the study. Rural patients (according to their home addresses) were selected at random from outpatient records of patients who had attended the clinics during the previous five years. They were sent an introductory letter asking them to cooperate in the study. Age and sex matched controls were randomly chosen from the municipal registry of the city of Enschede and from five surrounding villages in the same rural area. The controls were also sent a letter asking for their cooperation.

All patients and control subjects were visited in their homes by the same interviewer, who read the

Table 1 Age, sex, and functional grading, ${ }^{9}$ according to the rheumatologist, in patients with arthritis and in controls

\begin{tabular}{|c|c|c|c|c|}
\hline & \multicolumn{2}{|l|}{ Urban } & \multicolumn{2}{|l|}{ Rural } \\
\hline & $\begin{array}{l}\text { Patients } \\
(n=100) \\
(\%)\end{array}$ & $\begin{array}{l}\text { Controls } \\
(n=103) \\
(\%)\end{array}$ & $\begin{array}{l}\text { Patients } \\
(n=102) \\
(\%)\end{array}$ & $\begin{array}{l}\text { Controls } \\
(n=100) \\
(\%)\end{array}$ \\
\hline $\begin{aligned} \text { Sex: } & \text { male } \\
& \text { female }\end{aligned}$ & $\begin{array}{l}23 \\
77\end{array}$ & $\begin{array}{l}31 \\
69\end{array}$ & $\begin{array}{l}37 \\
63\end{array}$ & $\begin{array}{l}35 \\
65\end{array}$ \\
\hline $\begin{array}{l}\text { Median age } \\
\text { (years) } \\
\text { (range) }\end{array}$ & $\begin{array}{l}65 \\
(35-87)\end{array}$ & $\begin{array}{l}65 \\
(45-80)\end{array}$ & $\begin{array}{l}59 \\
(29-84)\end{array}$ & $\begin{array}{l}60 \\
(30-88)\end{array}$ \\
\hline $\begin{array}{l}\text { Disease duration } \\
\text { (years) }\end{array}$ & 15 & & 15 & \\
\hline $\begin{array}{l}\text { Functional grading } \\
\text { Grade 1: fit for } \\
\text { all activities }\end{array}$ & 0 & & 2 & \\
\hline $\begin{array}{l}\text { Grade 2: moderate } \\
\text { restriction }\end{array}$ & 38 & & 32 & \\
\hline $\begin{array}{l}\text { Grade 3: marked } \\
\text { restriction }\end{array}$ & 51 & & 52 & \\
\hline $\begin{array}{l}\text { Grade } 4: \text { confined } \\
\text { to chair or bed }\end{array}$ & 11 & & 13 & \\
\hline
\end{tabular}

questions, with explanations if necessary, and noted the answers.

A structured questionnaire, a version adapted from Buchanan and Chamberlain, ${ }^{4}$ was used to record age, sex, occupation, marital status, disease duration, and number of household members; financial situation of the subject; attitude towards the arthritic disease; mobility inside and outside the house; contacts with medical and social services; home aids and adaptations, the financing of these, the type of housing and knowledge about availability of grants, aids, and adaptations; and the wishes and expectations as expressed by the subjects of improving their situation.

All statistical analyses were carried out on a PDP11/44 minicomputer with the $\chi^{2}$ test and a normal approximation of the binomial test.

\section{Results}

The response rate of the urban patients was $100 \%$ and of the rural patients $90 \%$. Thus 77 urban subjects with RA and 23 with OA and 93 rural patients with RA and nine with OA were visited in their homes. We have combined the results of RA and $\mathrm{OA}$ because there were no significant differences between them (either in the urban or the rural subjects). Details of their disease duration, severity of functional grading, ${ }^{7}$ age, and sex are summarised in Table 1 . The results of the comparison of rural and urban subjects remained consistently the same after standardising for age.

The total number of single (unmarried, separated, divorced, or widowed) patients in the city and countryside was not significantly different from that of controls, nor from that of the Dutch population of the same age (Table 2). In the rural areas more than

Table 2 Social situation, age of housing, and distances to public transport and supermarket

\begin{tabular}{|c|c|c|c|c|c|}
\hline & \multicolumn{2}{|l|}{ Urban } & \multicolumn{2}{|l|}{ Rural } & \multirow{2}{*}{$\begin{array}{l}\text { General Dutch } \\
\text { population } \\
>45 \text { years } \\
(\%)\end{array}$} \\
\hline & $\begin{array}{l}\text { Patients } \\
(n=100) \\
(\%)\end{array}$ & $\begin{array}{l}\text { Controls } \\
(n=103) \\
(\%)\end{array}$ & $\begin{array}{l}\text { Patients } \\
(n=102) \\
(\%)\end{array}$ & $\begin{array}{l}\text { Controls } \\
(n=100) \\
(\%)\end{array}$ & \\
\hline Married & 72 & 78 & 74 & 79 & 72 \\
\hline Unmarried & 3 & - & 10 & 4 & 8 \\
\hline Divorced & 2 & 1 & - & 1 & 3 \\
\hline Widow(er) & 23 & 21 & 16 & 16 & 17 \\
\hline Car owner & 53 & 47 & 64 & 76 & \\
\hline Houses built before 1931 & 15 & 12 & 38 & 29 & \\
\hline \multicolumn{6}{|l|}{ Distance to: } \\
\hline $\begin{array}{l}\text { bus stop }<200 \mathrm{~m} \\
\text { railway station }\end{array}$ & 49 & 49 & 25 & 24 & \\
\hline$<2 \mathrm{~km}$ & 48 & 44 & 8 & 14 & \\
\hline$<5 \mathrm{~km}$ & 86 & 88 & 20 & 28 & \\
\hline \multicolumn{6}{|l|}{ to supermarket } \\
\hline$<500 \mathrm{~m}$ & 85 & 85 & 51 & 37 & \\
\hline
\end{tabular}


half of the single people lived in another household, often that of a brother, sister, or child (patients $50 \%$, controls $60 \%$ ), but in the town only one fifth did so. In the town all single subjects who were dependent on others for their activities of daily living $(15 \%)$ were living in homes for the aged or nursing homes, compared with $3 \%$ in the villages.

In general the urban patients and controls lived in more modern houses, their distances to the shops were shorter, and they were better served with public transport (Table 2). Both patient groups had the same amount of difficulty outside the house, for example with steps, uneven pavement surfaces, high curbs, or traffic, and both groups mentioned equal difficulties when using buses or trains (Table 3).

Although one would expect more difficulties with roads in villages, the rural patients more frequently went out of their homes; predictably the controls went out more often (Table 4). (The exact question was 'If you add all your activities like shopping, visiting people, going for a walk, going to your work, how frequently do you go outside your

Table 3 Difficulties in the street and with transport

\begin{tabular}{|c|c|c|c|c|}
\hline & \multicolumn{2}{|l|}{ Urban } & \multicolumn{2}{|l|}{ Rural } \\
\hline & $\begin{array}{l}\text { Patients } \\
(n=100) \\
(\%)\end{array}$ & $\begin{array}{l}\text { Controls } \\
(n=103) \\
(\%)\end{array}$ & $\begin{array}{l}\text { Patients } \\
(n=I 02) \\
(\%)\end{array}$ & $\begin{array}{l}\text { Controls } \\
(n=I 00) \\
(\%)\end{array}$ \\
\hline Curbs & 64 & 21 & 53 & 7 \\
\hline Uneven surfaces & 61 & 27 & 66 & 11 \\
\hline Traffic & 21 & 9 & 27 & 2 \\
\hline No complications & 20) & 67 & 27 & 89 \\
\hline \multicolumn{5}{|c|}{ Problems getting into } \\
\hline bus & 55 & 18 & 43 & 4 \\
\hline train & Not asked & 14 & 25 & 13 \\
\hline car & 54 & 19 & 39 & 2 \\
\hline
\end{tabular}

Table 4 Total numbers of outings

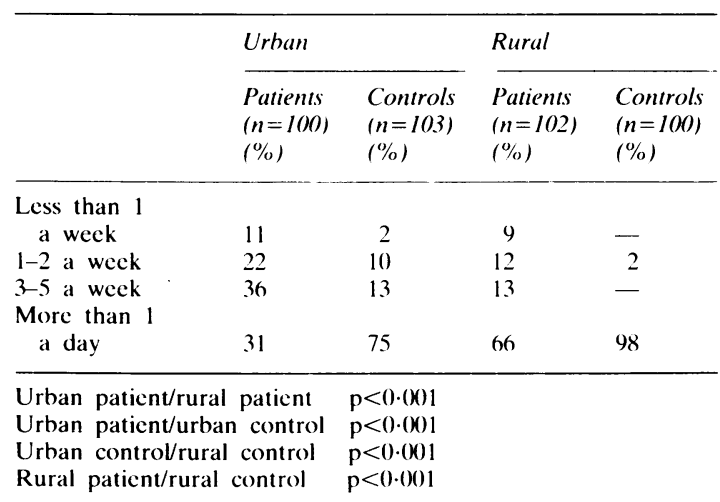

home?') Although both patient groups had the san? functional capacities (Table 1), in the countrysige more sufferers were still using their bicycles, and the distance which could be walked without resting w⿳亠丷厂犬s significantly shorter for urban than for rural patients. Also, the urban controls appeared to less able than the rural ones. The walking distane was significantly shorter in both patient groups th in the control groups (Table 5).

Rural patients went more frequently to pubfic places such as the pharmacy, bank, post office, than their urban counterparts; both groups went less than the control groups (Table 6).

These differences cannot be explained economic factors or quality of public transport or car ownership (difference not significant). The supert market was the only shop that was visited by about half of the patients in both groups and by mog controls $(\mathrm{p}<0.001$ for urban patient/urban controd,

Table 5 Use of bicycle and walking distance as mention by rural and urban patients with arthritis and by contro\$

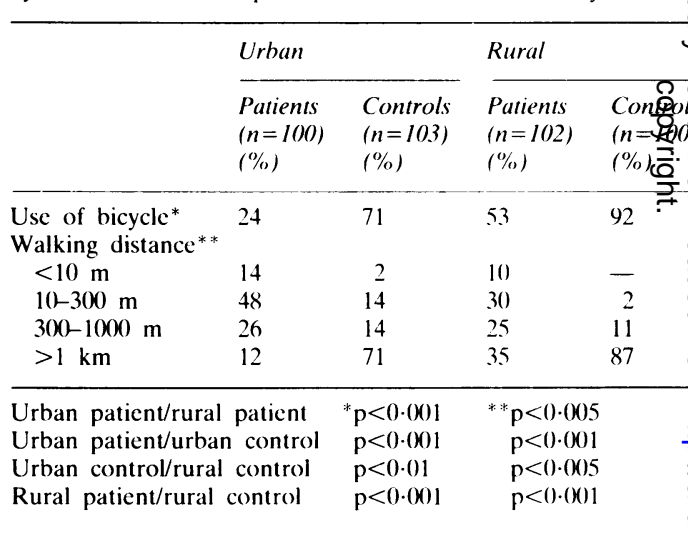

Table 6 Visits to bank, post office, and to different shợs (bakery, dairy, butcher, greengrocer, grocery) and supermarket

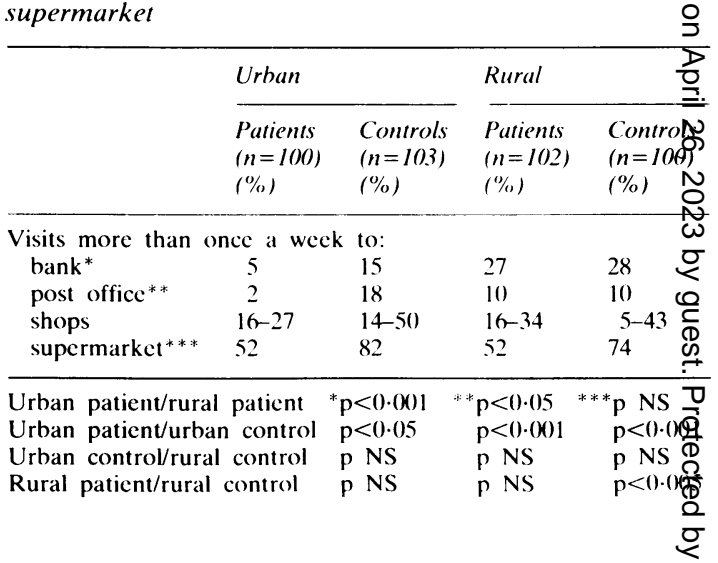


$\mathrm{p}<0.005$ for rural patient/rural control); all other shops such as the baker, butcher, or dairy were visited equally often by patients and controls (only slightly more frequently by the urban comparison group, Table 6).

The patients and controls almost never went to a cinema and equally seldom to a museum or theatre; this apparently depended more on age than on the lack of mobility. The library was visited more frequently by controls than by patients, especially in town. The hospital was the only place where urban rheumatism sufferers went significantly more frequently (urban patient/rural patient, $\mathrm{p}<0 \cdot 001$ ).

The urban and rural patient groups met their friends and relatives equally often, but more than half the urban patients received them in their homes, whereas the rural patients went out more frequently to see them $(p<0 \cdot 001)$. Of the urban patients, $35 \%$ expressed a wish to meet friends and relatives more frequently, and only $10 \%$ of the rural patients expressed this desire (control group 10\% and $4 \%$ respectively).

Adaptations in the homes, such as adapted toilets or showers, were found equally in the houses of urban $(46 \%)$ and rural $(43 \%)$ patients.

Both groups were especially restricted in active hobbies such as sewing and gardening, and patients

Table 7 Active and passive hobbies

\begin{tabular}{llllll}
\hline & \multicolumn{3}{l}{ Urban } & & \multicolumn{2}{l}{ Rural } \\
\cline { 2 - 3 } \cline { 5 - 6 } & $\begin{array}{l}\text { Patients } \\
(n=100) \\
(\%)\end{array}$ & $\begin{array}{l}\text { Controls } \\
(n=103) \\
(\%)\end{array}$ & $\begin{array}{l}\text { Patients } \\
(n=102) \\
(\%)\end{array}$ & $\begin{array}{l}\text { Controls } \\
(n=100) \\
(\%)\end{array}$ \\
\hline $\begin{array}{lllll}\text { Active hobbics } \\
\text { Passive hobbics }\end{array}$ & 21 & 58 & 52 & 70 \\
No hobbics & 21 & 62 & 60 & 58 \\
\hline
\end{tabular}

and controls spent a similar time on passive hobbies (watching TV, reading) (Table 7).

Most patients had little contact with the members of 'the treatment team', including the general practitioner, social worker, and district nurse. Only the domestic help was seen regularly (Table 8 ). The activities of the district nurses consisted of a conversation with two thirds of their patients $(70 \%$ urban, $74 \%$ rural), which all subjects appreciated very much. During these visits the patient was rarely advised about adaptations, subsidies, or aids.

Many of our patients went to alternative healers such as homeopaths (Table 9).

During the interview the subjects were asked in what way they would like to improve their situation; this was put as an open question without giving further suggestions (Table 10). More than half wanted to have more information about their illness, treatment, and where to get subsidies for aids and for home adaptations. For most patients finances

Table 9 Alternative treatments applied by patients and controls

\begin{tabular}{|c|c|c|c|c|}
\hline \multirow{2}{*}{$\begin{array}{l}\text { Alternative } \\
\text { treatments }\end{array}$} & \multicolumn{2}{|l|}{ Urban } & \multicolumn{2}{|l|}{ Rural } \\
\hline & $\begin{array}{l}\text { Patients } \\
(n=100) \\
(\%)\end{array}$ & $\begin{array}{l}\text { Controls } \\
(n=103) \\
(\%)\end{array}$ & $\begin{array}{l}\text { Patients } \\
(n=102) \\
(\%)\end{array}$ & $\begin{array}{l}\text { Controls } \\
(n=100) \\
(\%)\end{array}$ \\
\hline Mesmerism & 36 & 15 & 27 & 11 \\
\hline Homeopathy & 13 & 23 & 19 & 5 \\
\hline Herbalism & 4 & 3 & 4 & - \\
\hline Acupuncture & 1 & 3 & 7 & 1 \\
\hline Other & 13 & 13 & 9 & 1 \\
\hline Any method* & 56 & 39 & 53 & 15 \\
\hline \multicolumn{2}{|c|}{$\begin{array}{l}{ }^{*} \text { Urban patient/rural patient } \\
\text { Urban patient/urban control } \\
\text { Urban control/rural control } \\
\text { Rural patient/rural control }\end{array}$} & $\begin{array}{l}\text { NS } \\
\mathrm{p}<0 \cdot 025 \\
\mathrm{p}<0 \cdot 001 \\
\mathrm{p}<0 \cdot 001\end{array}$ & & \\
\hline
\end{tabular}

Table 8 Contacts with professional helpers

\begin{tabular}{|c|c|c|c|c|}
\hline \multirow{2}{*}{$\begin{array}{l}\text { Minimum } \\
\text { frequency } \\
\text { of } \\
\text { visit }\end{array}$} & \multicolumn{2}{|l|}{ Urban } & \multicolumn{2}{|l|}{ Rural } \\
\hline & $\begin{array}{l}\text { Patients } \\
(n=100) \\
(\%)\end{array}$ & $\begin{array}{l}\text { Controls } \\
(n=103) \\
(\%)\end{array}$ & $\begin{array}{l}\text { Patients } \\
(n=102) \\
(\%)\end{array}$ & $\begin{array}{l}\text { Controls } \\
(n=100) \\
(\%)\end{array}$ \\
\hline Weckly & 35 & 26 & 37 & 12 \\
\hline Monthly & 30 & 5 & 35 & 5 \\
\hline Monthly & 13 & 10) & 25 & 10 \\
\hline Ycarly & 10 & 3 & 6 & 1 \\
\hline
\end{tabular}

${ }^{*}$ Urban paticnt/rural patient NS

Urban patient/urban control NS

Urban control/rural control $\mathrm{p}<0 .(15$

Rural paticnt/rural control $\mathrm{p}<() \cdot()()) 1$ 
were less important. Other wishes like parking permits, domestic help, or old age pensions were occasionally expressed.

ATTITUDE TOWARDS THE DISEASE, MAIN COMPLAINTS

For two thirds of the patients the main problem was the feeling of dependency and of being unable to do the things they used to do (Table 11). Only a minority of the rural and the urban patients mentioned pain as the main disadvantage of their disease. There was no relationship with severity of disease or functional capacity and pain. These results remained the same after standardising for RA and OA. During our investigations many further problems were mentioned by the patients. As these questions were not asked systematically no quantitative figures are available. They included fluctuations in the severity of the disease, problems

Table 10 Improvements in their situation desired by patients with arthritis and by controls*

\begin{tabular}{|c|c|c|c|c|}
\hline & \multicolumn{2}{|l|}{ Urban } & \multicolumn{2}{|l|}{ Rural } \\
\hline & $\begin{array}{l}\text { Patients } \\
(n=100) \\
(\%)\end{array}$ & $\begin{array}{l}\text { Controls } \\
(n=103) \\
(\%)\end{array}$ & $\begin{array}{l}\text { Patients } \\
(n=102) \\
(\%)\end{array}$ & $\begin{array}{l}\text { Controls } \\
(n=100) \\
(\%)\end{array}$ \\
\hline More information & 56 & 20 & 55 & 1 \\
\hline $\begin{array}{l}\text { Adaptations } \\
\text { in the street }\end{array}$ & 27 & - & 1 & 1 \\
\hline $\begin{array}{l}\text { Adaptations at } \\
\text { home }\end{array}$ & 24 & 5 & 11 & 1 \\
\hline $\begin{array}{c}\text { Adaptations } \\
\text { in official } \\
\text { buildings }\end{array}$ & 21 & 17 & 28 & 17 \\
\hline Other adaptations & 14 & 1 & 3 & - \\
\hline Financial help & 10 & 13 & 19 & 15 \\
\hline Other & 20 & 36 & 24 & 15 \\
\hline
\end{tabular}

${ }^{*}$ The exact question was 'If I ask you what can be done to improve your situation, for instance, financial, adaptations, housing, help, etc, what would be your answer?'

Table 11 Main disadvantage of the rheumatic disease

\begin{tabular}{lll}
\hline & $\begin{array}{l}\text { Urban patients } \\
(n=100) \\
(\%)\end{array}$ & $\begin{array}{l}\text { Rural patients } \\
(n=102) \\
(\%)\end{array}$ \\
\hline $\begin{array}{lll}\text { Not being able } \\
\text { to do things }\end{array}$ & 36 & \\
Feeling dependent & 32 & 46 \\
Pain & 17 & 19 \\
Physical complaints & - & 13 \\
Tiredness & - & 5 \\
Other & 5 & 2 \\
Combination & 9 & 1 \\
No disadvantage & 1 & 7 \\
\hline
\end{tabular}

Table 12 Satisfaction with current situation

\begin{tabular}{|c|c|c|c|c|}
\hline & \multicolumn{2}{|l|}{ Urban } & \multicolumn{2}{|l|}{ Rural } \\
\hline & $\begin{array}{l}\text { Patients } \\
(n=I 00) \\
(\%)\end{array}$ & $\begin{array}{l}\text { Controls } \\
(n=103) \\
(\%)\end{array}$ & $\begin{array}{l}\text { Patients } \\
(n=102) \\
(\%)\end{array}$ & $\begin{array}{l}\text { Controts } \\
(n=10 \text { 娄 } \\
(\%)\end{array}$ \\
\hline Content & 38 & 81 & 68 & 94 \\
\hline Rather content ? & & 15 & 24 & 6 \\
\hline Discontent & 62 & 4 & 8 & - \\
\hline
\end{tabular}

Urban patient/rural patient $\mathrm{p}<0.001$

Urban patient/urban control $\mathrm{p}<0.001$

Urban control/rural control $\mathrm{p}<0.01$

Rural patient/rural control $\quad \mathrm{p}<0.001$

with the partner of the patient, and the changing prospects of the patient and his family.

In the light of these problems one might exped that patients with arthritis were less content wigh their current situation than both control groups (Table 12). The matter was explored in the questionnaire by asking 'When I ask you how you feel about your life now, would you say "I क्षे content, rather content, or discontented?"'. It wass found that the control groups were more conteret than the arthritic patients; in addition, rural patiens seemed to be more content than urban ones apd rural controls were more content than those intope city.

\section{Discussion}

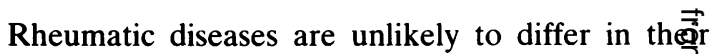
course and severity in the countryside as opposed to the cities, nevertheless many differences emerge the attitude of rural and urban patients. Our figures indicate that rural patients cope with their disease better, being able to do more, and actually doing more, than their urban counterparts. Although the rural patients were slightly younger as a group, the functional capacity was the same in both groups. have no clear explanation for this difference in ags. It might by explained by the selection method, but as almost all rural and urban patients were undor regular supervision this seems unlikely. Ruraìl patients are also more content with their fate (Tabue 12), though their houses are older, less frequently centrally heated, distances are longer, and streess are worse; this despite the fact that functiongl grading was the same in both groups and the resuftis remained the same when standardised for age. They appear to be more mobile, more able to walk longor distances, and to use their bicycles; this may be reflection of need, but as most patients had a car this seems unlikely. Shopping provided difficulties fơr many patients, only the supermarket was visite 
regularly. A slight discrepancy seems to exist between Tables 1 and 5 . The functional grading (Table 1) was performed by the rheumatologist, and $11 \%$ and $13 \%$ of the patients respectively were graded as confined to chair or bed. Table 5 shows the figures as stated by the patients themselves and here $14 \%$ and $10 \%$ are said to be unable to walk 10 metres. These figures may be explained by day to day changes or an optimistic view.

When this study started, newer methods like AIMS $^{11}$ for measuring functional disability were not yet available. We chose to use the Steinbrocker ${ }^{9}$ and Amalia Harris ${ }^{10}$ systems, which were also applied by Buchanan and Chamberlain. ${ }^{5}$ As the results of the Amalia Harris classification did not really add to our findings, ${ }^{3}$ these have been omitted from this report.

In the rural area around Enschede many people have lived in the same village for generations and family ties are strong. This may explain why these people tend to care more for their single relatives, whether handicapped or not, and also to care more than those in the town for handicapped parents, brothers and sisters, or even neighbours. ${ }^{12}$ Frequently next to the farmhouse a small house has been built for parents and they participate in the family life, e.g., by looking after grandchildren, doing some gardening, or milking. In general, disabled people without a partner are taken into the household of one of the healthy family members. While this is not the case in the cities, it does also apply to the rural control group.

In the Netherlands the number of single people older than 65 years, living with somebody else or in another household has dropped since 1960 from $40 \%$ to $6 \%$ in $1976 .{ }^{13}$ These figures fit in very well with our findings in the town. It may be that people in town have less room for their relatives, but many no longer feel personally responsible for their old and handicapped relatives or neighbours and tend to put them in homes for the aged. ${ }^{14}$ We hope that this tendency in town will not become commonplace in the countryside as well, but the national figures are not promising. ${ }^{2}$

It appears from our study that patients with rheumatism want more information about the social services and the way to obtain aids and subsidies; the complicated structure of these services may be one explanation of this need. The patients had little contact with many helpers; comparable figures are found in a later study in Amsterdam/Groningen and surrounding countryside. ${ }^{15}$

Some further problems were mentioned by the subjects. In the later study ${ }^{15}$ these were measured and our first impressions were confirmed. Sixty five per cent mentioned day to day fluctuations in disease activity and symptoms and half of these experienced greater or less difficulty owing to this phenomenon, especially those who were more dependent on other people for their ADL activity. In $21 \%$ of patients the illness had greatly influenced their relationship with their partner and the whole family, again mainly in the more severe cases. Many patients $(31 \%)$ expressed great anxiety for their future. ${ }^{15}$

Significantly, most of our rheumatic sufferers did not mention pain as the main disadvantage of the disease, but rather the lack of independency and the lack of mobility (Table 11). Similar results were found in Leeds and rural Wiltshire ${ }^{56}$ and in a second study in Holland ${ }^{15}$; this is a finding of considerable importance to general practitioners, who are probably more concerned with the relief of pain than with the provision of relevant services and aids to independence. It also points to the need to educate medical students about this. Thus it seems advisable in the treatment of the rheumatic patient to concentrate on improving independence and mobility rather than prescribing pain killers.

Our survey gives us some idea about the perceptions of the patients. They in fact are the central figures in the total management and they decide what is going to happen, which tablet they will take, ${ }^{16}$ or what alternative help they will seek. (About $50 \%$ of patients seek alternative help at least once $^{217-19}$.)

Patients living in villages appear to be happier and also more independent. It is likely that the support of the neighbourhood plays an important part. It is therefore necessary not only to pay attention to the material situation of the patient ${ }^{20}$ but also to the community or society approach.

The most frequently expressed wishes were for more information about grants and home adaptations. Although this was a reply to an open question, confrontation with the interviewer may have influenced the answer. In a later study, ${ }^{15}$ however, the same results were found, suggesting that the bias was probably minimal.

This study was made possible by a grant from The Netherlands Rheumafonds. We are grateful to Drs A St John Dixon and M A Chamberlain for critically reading the manuscript, Dr J J M Festen for his cooperation, and Mrs W H Verduin-Keppel for typing the manuscript.

\section{References}

1 Hacker A. The end of the American family. Intermediair 1982; 18: $1-5$.

2 Mootz M. Timmermans J. Care for later. 's-Gravenhage: Staatsuitgeverij. 1981. (Sc P Cahier 26.)

3 Cornelissen P G J. Fear of thresholds. A study into the mobility and social aspects of arthritics. Rotterdam: Rotterdam University, 1984. (MD thesis.)

4 Chamberlain M A. Buchanan J M. Hanks H. The arthritic in an urban environment. Ann Rheum Dis 1979; 38: 51-6. 
5 Buchanan J M, Chamberlain M A. Survey of the mobility of the disabled in an urban environment. London: The Royal Association for Disability and Rehabilitation, 1982.

6 Buchanan J M. The mobility of disabled people in a rural environment. London: The Royal Association for Disability and Rehabilitation, 1982.

7 Central bureau for statistics. Population of Dutch municipality on Jan 1st 1979. 's-Gravenhage: Staatsuitgeverij, 1979.

8 Ropes M W, Bennett G A, Cobb S, Jacox R, Jessar R A. 1958 revision of the diagnostic criteria for rheumatoid arthritis. Ann Rheum Dis 1959; 18: 49-53.

9 Steinbrocker O, Tracger C H, Batterman R C. Therapcutic criteria in rheumatoid arthritis. JAMA 1949; 140: 659-62.

10 Harris A. Handicapped and impaired in Great Britain (part 1). London: HMSO, 1971

11 Meenan R F. The AIMS approach to health status measurement. Conceptual background and measurement properties. $J$ Rheumatol 1982; 9: 785-8.

12 Hattinga Verschuren J C M, Proosdij S. Taking care of your wellbeing. Lochem: De Tijdstroom, 1983.
13 Social and cultural planning bureau. Social and cultural repor 1980. 's-Gravenhage: Staatsuitgeverij, 1981.

14 Boer de F, Boutellier H. Family therapy and emotion Psychology and Society 1982; 20: 329-47.

15 Rasker J J, Bronner A E, Verzijden D, et al. To have arthriti What it means to be a patient with rheumatoid arthritis. A $\overrightarrow{7}$ investigation in 200 patients. Etten-Leur: Lederle Netherland 1984.

16 Eisenberg L. What makes persons 'patients' and patients 'wellō Am J Med 1980; 69: 277-86.

17 Heye R, Dequeker J, Top S. The use of alternative treatment if patients with RA. Tijdschr Geneesk 1980; 36: 917-22.

18 Struthers G R, Scott D L, Scott D G I. The use of 'alternatives treatments' by patients with rheumatoid arthritis. Rheumatol Iif 1983; 3: 151-2.

19 Nienhuis R L F. Report on a questionnaire on the functioninfy of a rheumatological outpatient clinic. Ned Tijdschr Geneesk 1985; 9: 371-3.

20 Dixon A St J. Research is for now, too. J Rheumatol 1981; 361-3. 